\title{
Two-dimensional gel electrophoresis of membrane proteins from ectomycorrhizal fungi
}

\author{
B Henrion, $F$ Martin * \\ INRA, Centre de Recherches Forestières de Nancy, Laboratoire de Microbiologie Forestière, \\ Champenoux 54280 Seichamps, France
}

(Received 12 September 1991; accepted 10 April 1992)

\begin{abstract}
Summary - A membrane fraction was isolated from the ectomycorrhizal fungi Pisolithus tinctorius and Cenococcum geophilum and from eucalyptus ectomycorrhizas using differential centrifugation. This fraction contained microsomes free of mitochondrial or nuclear membranes and enriched in endoplasmic reticulum, Golgi, tonoplast and plasma membranes as determined from an analysis of marker enzymes and electron microscopy observations. Four methods of membrane protein solubilisation were assessed on silver-stained 2-dimensional polyacrylamide gels. Gels with limited background staining and streaking and with clearly resolved polypeptides were obtained when $P$ tinctorius and mycorrhizal proteins were extracted with $2 \%$ sodium dodecyl sulphate followed by acetone precipitation. On the other hand, the O'Farrell buffer containing urea and Nonidet P-40 was selected for solubilisation of $C$ geophilum membrane proteins. An optimization of solubilisation procedures is therefore required for each fungal species. The procedures described make possible the resolution required for meaningful qualitative and quantitative electrophoretic analysis of membrane proteins from ectomycorrhizal fungi and mycorrhizas.
\end{abstract}

Cenococcum geophilum / Eucalyptus globulus / Pisolithus tinctorius / ectomycorrhiza / electrophoresis / membrane protein / symbiosis-related protein

Résumé - Analyse électrophorétique bidimensionnelle des protéines membranaires de champignons ectomycorhiziens. La différenciation des ectomycorhizes induit de profondes modifications dans la biosynthèse des protéines des partenaires de l'association symbiotique. Les structures membranaires de l'interface symbiotique sont particulièrement affectées par ce processus développemental et il est apparu nécessaire d'étudier la composition protéique de ce compartiment cellulaire. La présente contribution décrit une technique de fractionnement permettant l'obtention d'une fraction microsomale, ayant un bon degré de pureté, à partir de champignons ectomycorhiziens et d'ectomycorhizes et une étude comparative de plusieurs traitements de solubilisation de protéines membranaires pour leur efficacité et leur compatibilité avec l'obtention de gels d'électrophorèse bidimensionnelle. Une fraction membranaire a été purifiée par centrifugation différentielle à partir du mycélium végétatif des champignons ectomycorhiziens Pisolithus tinctorius et Cenococcum geophilum et d'ectomycorhizes d'eucalyptus. L'observation par microscopie électronique à transmission de cette fraction membranaire (fig 1) confirme l'absence de contaminations par des organelles (mitochondries, noyaux, plastes). L'activité d'enzymes spécifiques des différents types de membranes cellulaires indique que cette fraction est enrichie en membranes plasmalemmiques, tonoplastiques, golgiennes et endoplasmiques (tableaux I et II). La nature des membranes purifiées devrait permettre l'étude des protéines de l'interface symbiotique et du système sécrétoire. Afin d'analyser

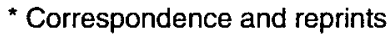


les protéines de cette fraction microsomale par électrophorèse sur gel de polyacrylamide à 2 dimensions, 4 protocoles de solubilisation des protéines ont été comparés (tableau III). Une solubilisation des protéines membranaires de $\mathrm{P}$ tinctorius et de mycorhizes par un tampon contenant $2 \%$ de dodécylsulfate de sodium, suivie d'une précipitation acétonique, favorise l'obtention de gels dépourvus de colorations parasites avec des polypeptides bien séparés (figs 3 et 4). Pour solubiliser efficacement les protéines membranaires de $\mathrm{C}$ geophilum, il est préférable de recourir au tampon de lyse de O'Farrell, riche en urée et Nonidet-P40 (fig 5). L'analyse électrophorétique des protéines membranaires de différentes espèces fongiques impose donc une optimisation préalable du protocole de solubilisation des protéines. Les protocoles de purification des membranes, de solubilisation des protéines membranaires et d'électrophorèse à 2 dimensions décrits dans cette contribution permettent d'aborder l'étude des modifications de la composition protéique des membranes au cours de la différenciation des ectomycorhizes.

Cenococcum geophilum / Eucalyptus globulus / Pisolithus tinctorius / champignon ectomycorhizien / électrophorèse / membrane / protéine de symbiose

\section{INTRODUCTION}

During the development of eucalyptus ectomycorrhizas, protein synthesis is considerably altered in response to morphological and physiological changes (Martin and Hilbert, 1991). Synthesis of SR (symbiosisrelated)- proteins and degradation of abundant root-specific polypeptides are typical features of ectomycorrhizal formation (Hilbert and Martin, 1988a, b; Hilbert et al, 1991). Ultrastructural studies have shown that the surface area of the plasma membrane and endoplasmic reticulum increases extensively in the ectomycorrhizal symbionts (Massicotte et al, 1987; Kottke and Oberwinkler, 1989). This increase is presumably associated with recognition, nutrient trafficking, and secreted protein biosynthesis (Smith and Smith, 1990; Martin and Hilbert, 1991). It is therefore likely that some of the SR-proteins are membrane-bound proteins involved in recognition, metabolite transport and protein secretion. However, investigation of the protein composition of symbiotic membranes has been limited by difficulty in membrane fractionation and solubilisation of membrane proteins. Hence, little is known about this cellular compartment at the molecular level.
The routine application of 2-D PAGE (2dimensional polyacrylamide gel electrophoresis) to the analysis of polypeptide components of fungal and plant membranes has proven to be difficult, often resulting in gels with low resolution, particularly in the high MW (molecular weight) range (Dupont and Leonard, 1980; Randall and Ruesink, 1983). The reason for these difficulties is not clearly understood, although aggregation of hydrophobic polypeptides and protease degradation are likely to be involved. To compare PAGE patterns, it is essential that proteins are well resolved, that gels are substantially free of streaking, smearing and background staining, lack artifacts due to proteolysis, and that protein patterns are reproducible from gel to gel. The apparent resistance of membrane proteins to electrophoretic analysis is probably the result of incomplete disruption of all protein complexes and aggregate formation during sample solubilisation (Dunn and Burghes, 1983). There are many detergents used in removing proteins from cell membranes, and there are several types of methods that can be used to purify integral membrane proteins (Hjelmeland and Chrambach, 1984; Van Renswoude and Kempf, 
1984). It therefore seemed of interest to compare the efficiency and reproducibility of different extraction procedures designed to enrich for membrane-bound proteins.

The purpose of the present investigation was to develop suitable methods for the isolation of a membrane fraction free of mitochondrial or nuclear membranes and for efficient solubilisation of membrane proteins in order to analyze them by 2-D PAGE.

\section{MATERIALS AND METHODS}

\section{Fungal inocula}

Cultures of Cenococcum geophilum $\mathrm{Fr}$ (isolate Sivrite) and Pisolithus tinctorius (presonal communication) Coker and Couch (isolate 441) were maintained in the collection of ectomycorrhizal fungi at the Laboratoire de Microbiologie Forestière (INRA, Nancy Forestry Research Center, Champenoux) as described in Martin et al (1983). $P$ tinctorius was grown on Pachlewski's medium in $2 \%$ agar (Martin et al, 1990) and $C$ geophilum was grown in liguid culture in Pachlewski's medium (Martin et al, 1983). Samples were removed from the pure cultures when required and stored at $-20^{\circ} \mathrm{C}$.

\section{Aseptic synthesis of ectomycorrhizas}

Seeds (seed lot No 16100) of Eucalyptus globulus ssp bicostata (Maid et an was provided by the Division of Forest Research (CSIRO, Australia). Media and methods for the growth of seedlings and the aseptic synthesis of ectomycorrhizas were as described by Malajczuk et al (1990) and Martin et al (1991).

\section{Membrane preparation}

Fungal mycelium and 7-day-old ectomycorrhizas $(100-300 \mathrm{mg})$ were sampled, weighed and immediately ground with a mortar and pestle at $4{ }^{\circ} \mathrm{C}$. Homogenization medium consisted of $10 \%$ (w/w) polyvinylpyrrolidone, $3 \mathrm{mM}$ EDTA, $25 \mathrm{mM}$ 2-ME (2-mercaptoethanol), $7.2 \mu \mathrm{g} / \mathrm{ml}$ PMSF (phenylmethylsulfonyl fluoride) and $25 \mathrm{mM}$ TrisMes (2-( $\mathrm{N}$-morpholino)ethane sulfonic acid) at a $\mathrm{pH}$ of 7.7 in $250 \mathrm{mM}$ sucrose, and was used at a ratio of $15 \mathrm{ml} \mathrm{g}^{-1}$ fresh weight of mycelium of ectomycorrhizas. PMSF, 2-ME and polyvinylpyrrolidone were added to the homogenization medium immediately prior to extraction. The homogenate was filtered through one layer of nylon membrane (outer diameter $48 \mu \mathrm{m}$ ) and centrifuged at $15000 \mathrm{~g}$ in a Kontron TFT 7038 rotor for $15 \mathrm{~min}$ at $4{ }^{\circ} \mathrm{C}$ to remove cell debris, nuclei and mitochondria. The pellet was discarded and the supernatant was centrifuged at $90000 \mathrm{~g}$ in a Kontron TFT 7038 rotor for $35 \mathrm{~min}$ at $4{ }^{\circ} \mathrm{C}$ to obtain the microsomal pellet. Microsomal pellets and the $90000 \mathrm{~g}$ supernatant were stored at $-20^{\circ} \mathrm{C}$ for further analysis.

\section{Solubilisation of membrane proteins}

Centrifuge tubes containing membrane pellets were inverted on ice and excess supernatant removed before addition of solubilisation buffers. Four methods were used to solubilize the microsomal fraction.

\section{Method 1}

The membrane pellet was suspended in $100 \mu \mathrm{l}$ of sodium dodecyl sulphate (SDS) buffer containing $2 \%(w / v)$ SDS, $2 \%(v / v)$ ME, 20\% (w/v) glycerol, and $2 \mathrm{mM}$ PMSF in $100 \mathrm{mM}$ Tris-HCl (pH 8.5) (Laemmli, 1970). The suspension was heated for $3 \mathrm{~min}$ at $80^{\circ} \mathrm{C}$. After cooling, the membrane residues were removed by centrifugation at $15000 \mathrm{~g}$ for $15 \mathrm{~min}$ at $4^{\circ} \mathrm{C}$.

\section{Method 2}

Membrane proteins were solubilized in $10 \mu \mathrm{l}$ of Laemmli buffer as described in method 1 and 2 vol of a sample dilution buffer consisting of 9.5 $M$ urea, $2 \%$ ( $/ / v$ ) Nonidet P40 (NP40), 5\% (v/v) 2-ME, and $2 \%(\mathrm{~V} / \mathrm{V})$ ampholytes (O'Farell, 1975) were added to the sample (Hurkman and Tanaka, 1986). 


\section{Method 3}

Membrane proteins were solubilized with $30 \mu \mathrm{l}$ of $9.5 \mathrm{M}$ urea, $2 \%(\mathrm{v} / \mathrm{v}) \mathrm{NP} 40,5 \%(\mathrm{v} / \mathrm{v}) 2-\mathrm{ME}$, and $2 \%(\mathrm{v} / \mathrm{v})$ ampholytes (O'Farrell, 1975) for $1 \mathrm{~h}$ at room temperature. Insoluble residues were removed by centrifugation $(15000 \mathrm{~g}$ for 60 $\min$ ).

\section{Method 4}

After solubilisation of membrane proteins corresponding to $300 \mathrm{mg}$ fresh weight by $300 \mu \mathrm{l}$ of buffer as described in method 1, four vol of cold $\left(-20^{\circ} \mathrm{C}\right)$ acetone was added, and the solution was incubated overnight at $-20{ }^{\circ} \mathrm{C}$. Proteins were precipitated by centrifugation at $15000 \mathrm{~g}$ for $10 \mathrm{~min}$, and the pellet was washed with cold $80 \%(\mathrm{v} / \mathrm{v})$ acetone. The pellet was solubilized in $30 \mu$ l of urea buffer consisting of $9.5 \mathrm{M}$ urea, $2 \%$ (v/v) NP40, 5\% (v/v) 2-ME, and 2\% (v/v) ampholytes (O'Farrell, 1975) for $1 \mathrm{~h}$ at room temperature, and insoluble material was removed by centrifugation at $15000 \mathrm{~g}$ for $1 \mathrm{~h}$ at room temperature.

All samples were loaded immediately onto polyacrylamide gels after preparation.

\section{Polyacrylamide gel electrophoresis}

Total proteins were extracted and separated by 1-D SDS-PAGE according to Hilbert and Martin (1988a). The membrane proteins obtained according to method 1 were separated by $1-D$ SDS-PAGE (Hilbert and Martin, 1988a), whereas those obtained by methods 2,3 , and 4 were separated by 2-D SDS-PAGE as described by O'Farrell (1975), and modified according to Hilbert and Martin (1988b). Briefly, samples containing approximately $200 \mu \mathrm{g}$ of proteins were loaded at the basic end of the focusing gels. Glass cylinders $(140 \times 1 \mathrm{~mm})$ containing the urea-polyacrylamide gels and $4 \%$ ampholytes (25\% ampholytes pH 3.5 to 10 (LKB) and $75 \%$ ampholytes $\mathrm{pH} 5$ to 7 (Pharmacia)) were used. Isoelectric focusing was conducted for $17.5 \mathrm{~h}$ at $1200 \mathrm{~V}$ plus $0.5 \mathrm{~h}$ at $1500 \mathrm{~V}$. Gels were extruded, equilibrated, and loaded onto the 2nd dimension as described by O'Farrell (1975), except that ME was omitted (Tasheva and Dessev, 1983). Proteins were silver-stained as in Blum et al (1987). Gels were then dried using a slab gel drier (Bio-Rad model 543).

The apparent MW and isoelectric point of polypeptides were estimated from their migration in the gel in relation to that of standard proteins with known MW (Pharmacia AB, Uppsala, Sweden) and isoelectric point (Isoelectric Point Calibration Kit, BDH, Poole, UK).

Data were derived from 3-6 replicate experiments with separate lots of samples.

\section{Protein assay}

Protein content was estimated using a Bio-Rad protein kit (Bradford, 1976) with bovine serum albumin as a standard.

\section{Electron microscopy}

Microsomal membranes were fixed with $2.5 \%$ $(\mathrm{w} / \mathrm{w})$ glutaraldehyde, then post-fixed in $2 \%(\mathrm{w} / \mathrm{w})$ osmium tetroxide. Specimens were dehydrated and embedded in Epon 812. Ultra-thin sections were cut with a diamond knife (80-nm sections) (LKB Ultramicrotome), double-stained with $2 \%$ uranyl acetate (Valentines, 1961) and $80 \mathrm{mM}$ lead citrate (Reynolds, 1963) and were then examined under a Zeiss EM 952 electron microscope.

\section{Enzyme assays}

Membrane ATPase (ATP phosphohydrolase; EC 3.6.1.3) activity was defined as Mg-dependent ATP hydrolysis. ATPase activity was measured in a $1-\mathrm{ml}$ reaction vol containing $9 \mathrm{mM}$ ATP, $9 \mathrm{mM}$ $\mathrm{MgCl}_{2}$ and $50 \mathrm{mM}$ Tris-Mes (pH 6.5). The reaction was started by addition of $15 \mu \mathrm{g}$ membrane proteins in a vol of $10 \mu \mathrm{l}$ and allowed to proceed for $60 \mathrm{~min}$ at $30^{\circ} \mathrm{C}$. Pi release was measured according to the procedure of Black and Jones (1983). Glucose-6-phosphate dehydrogenase (EC 1.1.1.49) (G6PDH) activity, characteristic of the cytosol, was measured in a $1-\mathrm{ml}$ reaction medium containing $20 \mathrm{mM}$ glucose-6-phosphate, 2 $\mathrm{mM}$ NADP and $100 \mathrm{mM}$ Tris- $\mathrm{HCl}(\mathrm{pH} \mathrm{8.0)}$. The reaction was started by addition of $70 \mu \mathrm{g}$ membrane proteins in $200 \mu \mathrm{l}$ and allowed to proceed 
for $15 \mathrm{~min}$ at $30^{\circ} \mathrm{C}$. Release of NADPH was measured at $340 \mathrm{~nm}$.

\section{RESULTS \\ Characterization \\ of the membrane fraction}

A microsomal fraction was isolated from the mycelium of the ectomycorrhizal fungi Cenococcum geophilum and Pisolithus tinctorius and from Eucalyptus globulus- $P$ tinctorius ectomycorrhizas by differential centrifugation. The problem of sampling a thousand ectomycorrhizas at the same developmental stage precluded further purification of the different membrane components (ie, endoplasmic reticulum, plasma and tonoplast membranes) on continuous sucrose and Percoll gradients. Bulk membrane fractions were thus used to characterize membrane proteins. Cytoplasmic contamination of the membrane fraction was assessed by transmission electron microscopy and marker enzymes.

Electron microscopy revealed that the membrane pellets consisted of microsomes and extended sheets of membranes (fig 1) devoid of any cytoplasmic

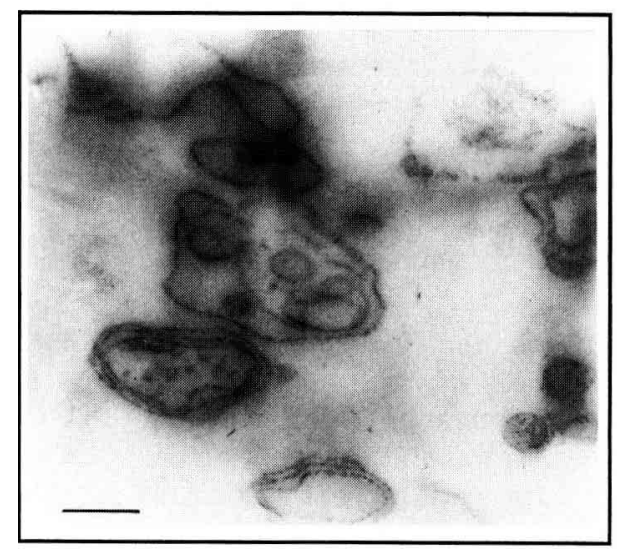

Fig 1. Thin sections of microsomal membranes from Pisolithus tinctorius from the final $90000 \mathrm{~g}$ pellet of the differential centrifugation. The fraction consists of membranes essentially as extended sheets and microsomes devoid of any mitochondria and cytosolic components. Scale marker $=1 \mu \mathrm{m}$.

contaminants and organelles including nuclei, mitochondria, lysosomes, and plastes. Cytosolic G6PDH and Mg-ATPase activity in the $90000 \mathrm{~g}$ pellet, the whole-cell homogenates and the supernatant fraction were compared (table I). The G6PDH and NADP-GDH (data not shown) activity in

Table I. Distribution of the cytosolic NADPH-glucose-6-phosphate dehydrogenase and Mg-dependent ATPase activities in different fractions during the purification procedure of membranes from Pisolithus tinctorius.

\begin{tabular}{|c|c|c|c|c|}
\hline \multirow[b]{3}{*}{ Fraction } & \multicolumn{4}{|c|}{ Enzyme activities } \\
\hline & \multicolumn{2}{|c|}{$N A D P H-G 6 P D H$} & \multicolumn{2}{|c|}{ Mg-ATPase } \\
\hline & $\begin{array}{r}\text { Specific } \\
\text { activity a }\end{array}$ & $\begin{array}{c}\text { Protein } \\
\text { ( } \mathrm{mg} \mathrm{g}^{-1} \text { fresh weight) }\end{array}$ & $\begin{array}{l}\text { Specific } \\
\text { activity } \mathrm{b}\end{array}$ & $\begin{array}{c}\text { Protein } \\
\text { (mg g }{ }^{-1} \text { fresh weight) }\end{array}$ \\
\hline Whole cell lysate & 41.95 & 1240 & 0.16 & 1020 \\
\hline Cytoplasmic fraction & 41.30 & 992 & 0.02 & 803 \\
\hline Purified membranes & 0.16 & 203 & 2.81 & 135 \\
\hline
\end{tabular}

a Specific activities were expressed as increase in absorbance at $340 \mathrm{~nm}$ (nkat $\mathrm{mg}^{-1}$ protein) for NADPH-G6PDH or as $\mathrm{Pi}$ released (nkat $\mathrm{mg}^{-1}$ protein) for the $\mathrm{Mg}$-dependent ATPase. 
the final membrane pellet accounted for only $0.5 \%$ of that of the whole cell lysate. On the other hand, the specific activity of $\mathrm{Mg}$-ATPase in the membrane preparation was 17 times that of whole cell lysate, indicating that the membrane fraction was enriched in plasma membrane.

SDS-PAGE patterns of total proteins, proteins from the cytosolic fraction, and proteins solubilized from purified microsomal membranes were compared for $C$ geophilum (fig 2). All the membrane polypeptides were present in the total protein

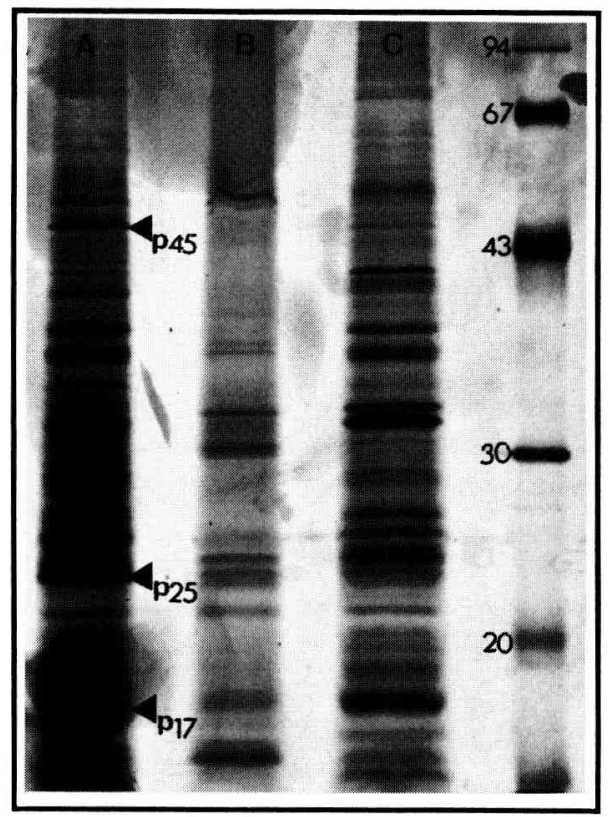

Fig 2. Comparison of 1-D SDS-PAGE of soluble proteins $(A)$, proteins solubilized from microsomal membranes (B), and total proteins (C) of Cenococcum geophilum. Lane $A$ to $C$ each contained $10 \mu \mathrm{g}$ total protein from the cytoplasmic fraction (lane A), SDS-extracted microsomal membrane (lane B), and TCA acetone extraction (Hilbert et al, 1988) (lane C). The right lane contained MW standards (size given in $\mathrm{kDa}$ ). All samples were reduced and denatured by heating to $100^{\circ} \mathrm{C}$ for $3 \mathrm{~min}$ in Laemmli sample buffer. fraction. Polypeptide patterns of the cytoplasmic and the membrane fractions were very different and the prominent soluble polypeptides (eg, p17, p25, and p45) were not detected in the membrane pattern, again indicating that there was little contamination of this fraction.

Differential sensitivity to inhibitors was used to distinguish ATPase activities which can serve as markers for different membranes (table II). Sodium azide, and inhibitor of mitochondrial ATPase (Gallagher and Leonard, 1987), had little effect on membrane ATPase activity, indicating a low contamination by mitochondrial ATPase. On the other hand, vanadate and nitrate strongly inhibited the enzyme activity suggesting that the preparation was considerably enriched in plasma and tonoplast membranes (Goffeau and Slayman, 1981).

Based on these investigations, we considered that: $i)$, the microsomal membranes

Table II. Properties of the Mg-dependent ATPase solubilized from microsomal membranes of Pisolithus tinctorius.

\begin{tabular}{ccc}
\hline & \multicolumn{2}{c}{ ATPase activity } \\
& Specific activity & \% Control \\
& & \\
\hline & & \\
Control & 2.81 & 100 \\
$-\mathrm{MgCl}$ & 0 & 0 \\
$+\mathrm{KCL}$ & 3.08 & 109 \\
$+\mathrm{NaN}$ & 2.47 & 88 \\
$+\mathrm{NaNO}_{3}$ & 1.06 & 58 \\
$+\mathrm{NaVO}_{3}$ & 0.75 & 26 \\
\hline
\end{tabular}

Microsomal proteins $(15 \mu \mathrm{g})$ were diluted to $100 \mu \mathrm{l}$ with buffer and treated as described in Materials and Methods. Percentage of inhibition by vanadate, azide and nitrate represents percentage of control activity inhibited by 5,7 , and $400 \mathrm{mM}$ sodium salts, respectively. The control medium contained $9 \mathrm{mM}$ ATP in Tris- $\mathrm{HCl}$, pH 6.5. a Enzyme activities were expressed as produced $\mathrm{Pi}$ (nkat $\mathrm{mg}^{-1}$ protein). 
obtained by differential centrifugation were free of organelles (including nuclei, mitochondria, lysosomes, plastes), as judged from electron microscopy; and ii), mitochondrial membranes were absent, as judged by marker enzymes. Since the nuclear membrane and the endoplasmic reticulum, and also the Golgi and the endoplasmic reticulum are contiguous, it is likely that these membranes are major constituents. Tonoplast, plasma membrane, and component of the protein secretory pathway are therefore present in this microsomal fraction.

\section{Solubilisation of membrane proteins}

Membrane proteins of $P$ tinctorius and $C$ geophilum were extracted with various buffers containing either an ionic (SDS) or a non-ionic (NP40) detergent. Extraction yields were higher (approximately $1 \mathrm{mg}$ protein. $g^{-1}$ fresh weight) with method $1(2 \%$ SDS) (table III), whereas the combination of the 2 detergents (method 2) gave lower yields. However, patterns of $C$ geophilum and $P$ tinctorius (data not shown) membrane proteins by 1-D PAGE showed that the quality of silver-stained gels and the number of polypeptides obtained with different methods of solubilisation were similar.
In contrast, analyses of fungal- and ectomycorrhiza-membrane proteins by $2-D$ PAGE showed that the quality of silverstained gels obtained following the different methods of solubilisation differed widely (figs 3, 4 and 5). Silver-stained gels of proteins solubilized from $P$ tinctorius membranes with $2 \%$ SDS followed by addition of NP40 and urea (method 2) had relatively few proteins and were characterized by horizontal and vertical streaking and high background staining (fig $3 \mathrm{~A}$ ). High background staining suggests incomplete solubilisation of the membrane sample leading to the formation of protein complexes and aggregates that remain at the top of the focusing gel or move slowly into the gel during focusing. When 2\% NP40 (method 3) and urea was used to solubilize membrane proteins (fig 3B), a larger number of polypeptides were present on 2-D gels. This increase in protein number coupled with decreased horizontal and vertical streaking indicated a more complete disaggregation of protein complexes during membrane solubilisation, but an intense background precluded the polypeptide analysis. Two-D gels of proteins recovered from membrane fractions solubilized by $2 \%$ SDS followed by acetone/2\% NP40 (method 4) showed limited horizontal and vertical streaking

Table III. Solubilisation of proteins from microsomal membranes of Pisolithus tinctorius and Cenococcum geophilum by 4 methods.

\begin{tabular}{|c|c|c|}
\hline \multirow[t]{2}{*}{ Method } & \multicolumn{2}{|c|}{ Solubilized protein $\mu g g^{-1} F W$} \\
\hline & Pisolithus tinctorius ( $\%$ ) & Cenococcum geophilum (\%) \\
\hline $\begin{array}{l}12 \% \text { SDS } \\
22 \% \text { SDS/2\% NP40 } \\
32 \% \text { NP40 } \\
4 \text { SDS/acetone/NP40 }\end{array}$ & $\begin{array}{l}990(100) \\
130(13) \\
420(42) \\
600(60)\end{array}$ & $\begin{array}{r}1130(100) \\
300(26) \\
700(62) \\
470(42)\end{array}$ \\
\hline
\end{tabular}

Microsomal membranes corresponding to the final $90000 \mathrm{~g}$ pellet of the purification procedure were solubilized and assayed as described in Materials and Methods. Data in this table are from a representative experiment. 

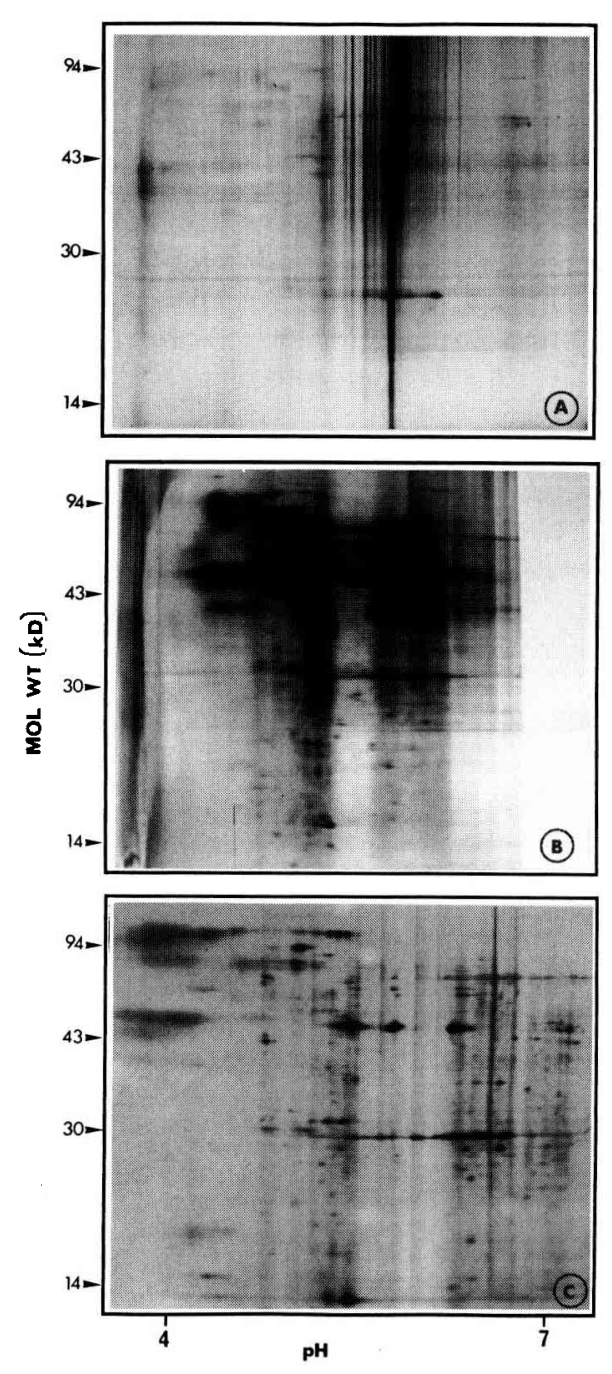

Fig 3. Two-dimensional PAGE of proteins solubilized from microsomal membranes from Pisolithus tinctorius. (A) membranes were initially solubilized in a buffer containing $2 \%$ SDS to which was added 2 vol of buffer containing urea and $2 \%$ NP40; (B) membranes were solubilized with the urea lysis buffer of O'Farrell; (C) membranes were solubilized with a buffer containing $2 \%$ SDS, precipitated and rinsed with acetone $(80 \%)$, and resolubilized in a buffer containing urea and $2 \%$ NP40. Each gel was loaded with $200 \mu \mathrm{g}$ of proteins.

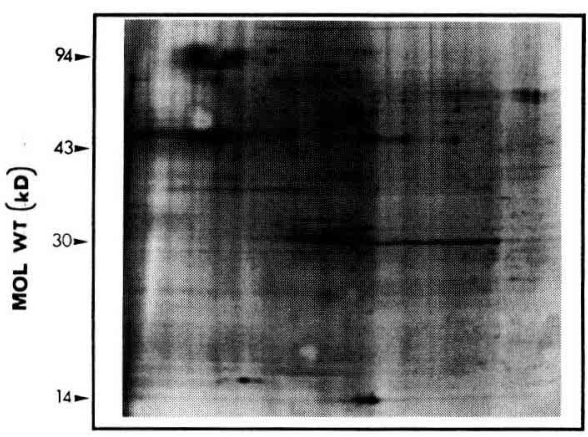

Fig 4. Two-dimensional PAGE of proteins solubilized from 7-day-old ectomycorrhizas of Eucalyptus globulus-Pisolithus tinctorius. Membranes were solubilized with a buffer containing $2 \%$ SDS, precipitated and rinsed with acetone, and resolubilized in a buffer containing urea and $2 \%$ NP40. The gel was loaded with $200 \mu \mathrm{g}$ of proteins.

and no background staining (fig 3C). Compared to 2-D gels of membrane proteins solubilized by other methods, protein gels solubilized by the latter method exhibited a larger number of polypeptides. Similarly, gels of membrane proteins from $E$ globulus- $P$ tinctorius mycorrhizas solubilized using this method exhibited a larger number of polypeptides as shown in figure 4 .

Two-D PAGE analysis of the membrane proteins from $C$ geophilum led to different conclusions. A greater number of polypeptides was observed (fig $5 \mathrm{C}$ ) in comparison to the other methods (fig $5 A, B$ ) when the urea lysis buffer ( $2 \%$ NP40, method 3 ) of O'Farrell was used to solubilize membrane proteins. No streaking and background staining were observed. Therefore, similar solubilisation methods may lead to a large difference in the 2-D patterns of membrane proteins from different fungi. The solubilisation of the membrane polypeptides may be altered by the cell wall and phenolic contents of the mycelium. 

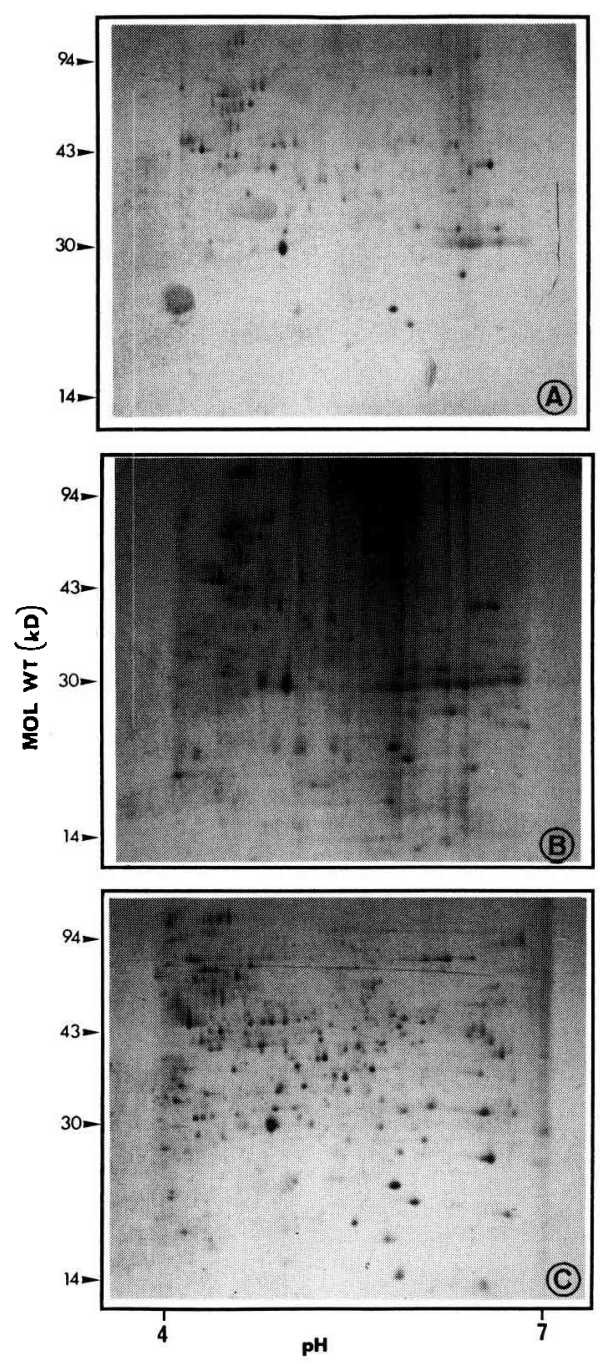

Fig 5. Two-dimensional PAGE of proteins solubilized from microsomal membranes from Cenococcum geophilum. (A) membranes were initially solubilized in a buffer containing $2 \%$ SDS to which was added 2 vol of buffer containing urea and $2 \%$ NP40; (B) membranes were solubilized with a buffer containing $2 \%$ SDS, precipitated and rinsed with acetone, and resolubilized in a buffer containing urea and $2 \%$ NP40; (C) membranes were solubilized with the urea lysis buffer of O'Farrell. Each gel was loaded with 200 $\mu \mathrm{g}$ of proteins.

\section{DISCUSSION}

Hardly any investigations have been carried out to characterize membrane-bound polypeptides in fungi. There are reports on polypeptides from Neurospora crassa (Bowman et al, 1981), Physarum polycephalum (Kuroda et al, 1989) and yeast (Goffeau and Slayman, 1981) membranes. No data are available on ectomycorrhizal fungi despite the well-known importance of the membranes at the symbiotic interface. The methods of membrane fractionation, protein solubilisation, and 2-D PAGE described in the present study constitute an attempt to determine optimum conditions for studying changes in membrane-protein patterns during ectomycorrhizal development (Martin and Hilbert, 1991).

Differential centrifugation allows a rapid and efficient purification of large membrane sheets and microsomal vesicules devoid of organellar contaminants as judged by electron microscopy. Enzymatic studies indicate that this fraction contained microsomes free of mitochondrial or nuclear membranes and enriched in tonoplast and plasma membranes (table II). Purification of the various membrane components (endoplasmic reticulum, golgi, tonoplastic and plasma membranes) of this bulk membrane fraction is required for detailed studies of specific membrane changes during mycorrhizal formation. However, sampling of thousands of ectomycorrhizas needed for a purification of specific membranes on sucrose density gradients is currently beyond experimental possibility. Surface-labelling of plasma membranes before cell lysis and membrane purification allowing identification of surface proteins is currently underway.

Four methods based on the use of both ionic and nonionic detergents have been assessed for solubilisation of membrane proteins for 2-D PAGE analysis. Solubilisation of membrane proteins for 2-D PAGE is 
difficult because most membrane proteins are tightly bound to membrane lipids, apparently by hydrophobic and ionic bonds. The choice and the quantity of detergent is very important (Selenger et al, 1969). Utilization of SDS usually leads to an excellent solubilisation of membrane proteins (Ames and Nikaido, 1976) but because of its ionic nature, proteins solubilized in SDS cannot be applied directly to isoelectric focusing gels. On the other hand, the urea lysis buffer originally recommended for sample solubilisation (O'Farrell, 1975) did not fully solubilize the membrane proteins (Ames and Nikaido, 1976).

Four solubilisation buffers used in the present study resulted in good separation of membrane proteins on 1-D PAGE. For 2-D PAGE, the different solubilisation procedures gave rise to different results with $C$ geophilum and $P$ tinctorius. The best 2-D membrane protein gels from the phenolic-rich $P$ tinctorius and $P$ tinctoriusEucalyptus mycorrhizas were obtained when membrane samples were solubilized in the SDS buffer (Laemmli, 1970) followed by acetone precipitation to remove SDS prior to solubilizing the proteins in the urea buffer (O'Farrell, 1975). The 2-D gels of proteins solubilized by the urea buffer and SDS/NP40 consistently showed high background staining, horizontal and vertical streaking, and exhibited a low number of polypeptides. These patterns may be due to the action of proteases and to inadequate solubilisation of the membrane samples (Uemura and Yoshiba, 1984). Solubilisation buffers containing SDS/ acetone/urea-NP40 and SDS/NP40 resulted in good separation of microsomal polypeptides from $C$ geophilum. However, less background staining was observed with the urea lysis buffer (O'Farrell, 1975).

In this investigation, we have shown that membrane polypeptides can be separated with good resolution by 2-D PAGE from small quantities of ectomycorrhiza or ectom- ycorrhizal fungi. Of the 4 methods assessed, 1 method (SDS/acetone/ureaNP40) enabled us to solubilize membrane polypeptides adequately, while the other 3 methods resulted in poor quality gels with $P$ tinctorius samples. Overall, the procedure described for membrane purification, together with the methods of membrane protein solubilisation and 2-D PAGE, should constitute good starting approaches for the study of changes in membrane polypeptide synthesis during ectomycorrhizal development.

\section{ACKNOWLEDGMENTS}

We wish to thank JL Hilbert and G Costa for their invaluable comments during the course of this investigation and R Pacovski for his helpful suggestions. This work was supported by a grant from the Institut National de la Recherche Agronomique (AIP "Régulation du Métabolisme des Associations Mycorhiziennes" grant No 88/ 4630) awarded to FM and by a doctoral fellowship of the Institut National de la Recherche Agronomique and the Région de Lorraine to $\mathrm{BH}$.

\section{REFERENCES}

Ames GFL, Nikaido K (1976) Two-dimensional gel electrophoresis of membrane proteins. Biochemistry 15, 616-623

Black MJ, Jones ME (1983) Inorganic phosphate determination in the presence of a labile organic phosphate: assay for carbamyl phosphate phosphatase activity. Anal Biochem 135, 233-238

Blum H, Beier H, Gross HJ (1987) Improved silver staining of plant proteins, RNA and DNA in polyacrylamide gels. Electrophoresis 8, 93-99

Bowman EJ, Bowman BJ, Slayman CW (1981) Isolation and characterization of plasma membranes from wild type Neurospora crassa. J Biol Chem 256, 12336-12342

Bradford MM (1976) A rapid and sensitive method for the quantitation of microgram quantities of protein utilizing the principle of proteindye binding. Anal Biochem 72, 248-254 
Dunn MJ, Burghes AHM (1983) High resolution 2-dimensional polyacrylamide gel electrophoresis. Methodological procedures. Electrophoresis 4, 97-116

Dupont FM, Leonard RT (1980) Solubilization and partial purification of the adenosine triphosphatase from a corn root plasma membrane fraction. Plant Physiol 65, 931-938

Gallagher SR, Leonard RT (1987) Electrophoretic characterisation of a detergent treated plasma membrane fraction from corn roots. Plant Physiol 83, 265-278

Goffeau A, Slayman CW (1981) The proteintranslocating ATPase of the fungal plasma membrane. Biochim Biophys Acta 639, 197223

Hilbert JL, Martin F (1988a) Modification des profils polypeptidiques lors de l'établissement de la symbiose ectomycorhizienne. Cryptogam Mycol 9, 221-231

Hilbert JL, Martin FM (1988b) Regulation of gene expression in ectomycorrhizas. I. Protein changes and the presence of ectomycorrhiza-specific polypeptides in the PisolithusEucalyptus symbiosis. New Phytol 110, 339346

Hilbert JL, Costa G, Martin F (1991) Ectomycorrhizin synthesis and polypeptide changes during the early stage of eucalypt mycorrhiza development. Plant Physiol 97, 977-984

Hjemeland LM, Chambach A (1984) Solubilization and functional membrane proteins. Methods Enzymol 104, 305-317

Hurkman WJ, Tanaka CH (1986) Solubilisation of plant membrane proteins for analysis by 2 dimensional gel electrophoresis. Plant Physiol 81, 802-806

Kottke I, Oberwinkler F (1989) Amplification of root-fungus interface in ectomycorrhizae by Hartig net architecture. Ann Sci For 46s, $737 \mathrm{~s}-740 \mathrm{~s}$

Kuroda T, Morita M, Okai K, Okamura S, Nishi A (1989) Isolation of plasma membrane and analysis of membrane glycoproteins from the slime mould Physarum polycephalum. J Gen Microbiol 135, 873-881

Laemmli UK (1970) Cleavage of structural proteins during the assembly of the head of bacteriophage T4. Nature 227, 680-685

Malajczuk N, Garbaye J, Lapeyrie F (1990) Infectivity of pine and eucalypt isolates of Pisol- ithus tinctorius on roots of Eucalyptus urophylla in vitro. New Phytol 114, 627-631

Massicotte HB, Peterson RL, Ackerley CA, Ashford $A E$ (1987) Ontogeny of Eucalyptus pilularis-Pisolithus tinctorius ectomycorrhizae. II. Transmission electron microscopy. Can J Bot 65, 1940-1947

Martin F, Hilbert JL (1991) Morphological, biochemical and molecular changes during ectomycorrhiza development. Experientia 47, 321-331

Martin F, Msatef Y, Botton B (1983) Nitrogen assimilation in mycorrhizas. Purification and properties of the nicotinamide adenine dinucleotide phosphate-specific glutamate dehydrogenase of the ectomycorrhizal fungus Cenococcum graniforme. New Phytol 93, 415-422

Martin F, Delaruelle C, Hilbert JL (1990) An improved ergosterol assay to estimate fungal biomass in ectomycorrhizas. Mycol Res 94, 1059-1064

O'Farrell PH (1975) High resolution 2dimensional electrophoresis of proteins. J Biol Chem 250, 4007-4021

Randall SK, Ruesink AW (1983) Orientation and integrity of plasma membrane vesicles obtained from carrot protoplasts. Plant Plysiol 73, 385-391

Reynolds ES (1963) The use of lead citrate at high $\mathrm{pH}$ as an electron opaque stain in electron microscopy. J Cell Biol 17, 208-212

Selinger Z, Klein M, Amsterdam A (1969) Properties of particles prepared from sarcoplasmic reticulum by deoxycholate. Biochim Biophys Acta 183, 19-26

Smith SE, Smith FA (1990) Structure and function of the interfaces in biotrophic symbioses as they relate to nutrient transport. New Phytol 114, 1-38

Tasheva B, Dessev G (1983) Artifacts in sodium dodecyl sulfate polyacrylamide gel electrophoresis due to 2-mercaptoethanol. Anal Biochem 129, 98-102

Uemura M, Yoshida S (1984) Involvement of plasma membrane alterations in cold acclimation of winter rye seedlings. Plant Physiol $75,818-826$

Valentines RC (1961) Contrast enhancement in the electron microscopy of viruses. Adv Viral Res 8, 287 